ZOOLOGIA 31 (3): 264-270, June, 2014

http://dx.doi.org/10.1590/S1984-46702014000300008

\title{
Reinstatement of Euarche rudipalpa (Polychaeta: Acoetidae), with remarks on morphology and body pigmentation
}

\author{
Sergio I. Salazar-Vallejo ${ }^{1,2,4}$, Alexandra E. Rizzo² \& Marcelo V. Fukuda ${ }^{3}$ \\ ${ }^{1}$ Estructura y Función del Bentos, Departamento de Sistemática y Ecología Acuática, ECOSUR. Chetumal, Quintana Roo, \\ México. E-mail: ssalazar@ecosur.mx \\ ${ }^{2}$ Departamento de Zoologia, Instituto de Biologia, Universidade do Estado do Rio de Janeiro. Maracanã, 20550-900 Rio de \\ Janeiro, RJ, Brazil E-mail: aerizzo@hotmail.com \\ ${ }^{3}$ Departamento de Zoologia, Instituto de Biociências, Universidade de São Paulo. 05508-090 São Paulo, SP, Brazil. \\ E-mail: fukuda@ib.usp.br \\ ${ }^{4}$ Corresponding author.
}

\begin{abstract}
Eupanthalis rudipalpa Amaral \& Nonato, 1984 was described based on three incomplete, colorless specimens and has not been reported since its original description; the epithet rudipalpa means "hirsute palps", a characteristic that separates it from other congeneric species. Eupanthalis McIntosh, 1876 and Euarche Ehlers, 1887, and their respective type species, E. kinbergi McIntosh, 1876 and E. tubifex Ehlers, 1887, were considered synonyms (E. rudipalpa as a junior synonym of E. tubifex, a cosmopolitan species) by some authors, because both have sessile eyes and two or three antennae. Nonetheless, these two genera are, in fact, distinct. Their type species can clearly be separated using some prostomial features. We provide an emended diagnosis of Euarche, and re-instate E. rudipalpa, redescribing it based on a Brazilian specimen (original type specimens lost). Illustrations showing body pigmentation pattern and a key to all species of Eupanthalis are also provided.
\end{abstract}

KEY WORDS. Acoetids; color pattern; Eupanthalis; key to species; Polychaetes.

Acoetid polychaetes are large, tubicolous worms that usually appear in very low densities in oceans; in most cases, species have been described based on single specimens and have seldom been recorded again (Buchanan 1894, Darboux 1899, Fauvel 1914a, Pettibone 1989). Amaral \& Nonato (1984) described Eupanthalis rudipalpa based on three incomplete, colorless specimens, and named it because it has hirsute palps, which separate it from other species. Probably following Fauchald (1977), they assigned their new species to Eupanthalis McIntosh, 1876. FAUCHALD (1977) was following the revision of the family by Buchanan (1894), who regarded Euarche Ehlers, 1887 as a junior synonym of Eupanthalis.

Eupanthalis was proposed by McInTosh (1876), with E. kinbergi as its type species. It is characterized by sessile eyes, whereas the other known genera have pedunculate eyes (BAIRD 1868, GRUBe 1876), and by having a pair of lateral antennae, but no median one: "There is no tentacle (= median antenna) in the specimen; but on each side of the median groove there is a filiform or slightly subulate antenna." (McIntosh 1876). Euarche was proposed by EhLERs (1887), with Euarche tubifex as the type species, for species that have sessile eyes (oculis non pedunculatis) and three antennae (tentaculis 3).

Buchanan (1894) reviewed Acoetidae and diagnosed Eupanthalis as having: "three prostomial tentacles, except (?) in E. tubifex" and explained this in a footnote: "McIntosh's remark that there is 'no' median 'tentacle in the specimen' (actually E. kinbergi but the quote was given for E. tubifex) seems rather to imply that there may once have been one, which has been lost by accident." Consequently, BuCHANAN mistook the type species of Eupanthalis and Euarche, and assumed that McIntosh had seen a species that came to be described 11 years later. Since these two genera were regarded as synonymous, thinking that their type species were also synonyms was probably an unavoidable consequence, and E. tubifex was regarded as a junior synonym of $E$. kinbergi by several taxonomists (FAUVEL 1914a, b, Augener 1918, Monro 1928, Hartman 1938).

Pruvot \& Racovitza (1895) objected the generic arrangement proposed by BuCHANAN, but their observations were overlooked by later authors. Despite the fact that the characters of the anterior end proposed by them have been later extensively used for separating similar genera, and their relevance was highlighted by FAUvel (1897): "Les meilleures caractères pour la classification des Acoetidés restent donc ceux tirés du nombre, de la forme et de l'implantation des appendices céphaliques et ceux tirés des soies et des parapodes", the best characters for acoetid classification are in the number, shape and insertion of cephalic appendages, and those of chaetae and parapodia. 
Pettibone (1989) regarded Eupanthalis and Euarche as distinct and re-established Euarche, indicating that Eupanthalis has two antennae, whereas Euarche has three. She also proposed a further difference between the two, which is the presence and extension of papillae along the palp's surface, being smooth in Eupanthalis or with papillae restricted to half their length, whereas in Euarche palps have papillae over at least two-thirds of their length. BARNICH \& FIEGE (2003) clarified the differences by indicating that Euarche has median antenna, and anterior chaetigers biramous, whereas in Eupanthalis there is no median antenna, and anterior chaetigers are subbiramous, usually without notochaetae.

Petтibone (1989) regarded some previously described species as junior synonyms of E. tubifex, including E. rudipalpa. Due to this expanded definition, E. tubifex ended up having a cosmopolitan distribution. The name encompassed specimens from the Gulf of Mexico (type locality), Gulf of Panama, Western Africa, South America, the Indian Ocean, and also specimens from Japan (IмајгмA 1997) and the Mediterranean Sea (Ben-Eliahu \& Fiege 1994, Barnich \& Fiege 2003). However, we believe that $E$. tubifex is composed of different species that can be separated by using features of the anterior end, as demonstrated in the present work. In this contribution we propose an emended diagnosis of Euarche, a redescription of E. rudipalpa re-establishing the taxon as a valid species; and provide illustrations based on recently collected material, showing the pigmentation pattern of the body. A key to all species of Euarche is also provided.

\section{MATERIAL AND METHODS}

One specimen was collected in the Santos Basin, in the Brazilian continental shelf. Some parapodia were removed and mounted in ethanol-glycerol for semi-permanent preparations. In one parapodium, chaetae were trimmed to observe their arrangement in frontal view, as suggested by IMAJIMA (1997). Some other parapodia were cross-sectioned to observe enteric diverticula. A series of digital photographs were stacked by using the Helicon Focus software. It is a program for focus stacking or, in other words, a post-processing technique that extends the depth of field in photographs. The material is deposited at the Polychaeta Collection, from Universidade do Estado do Rio de Janeiro (UERJ).

\section{TAXONOMY}

\section{Euarche Ehlers, 1887}

Type species. Euarche tubifex Ehlers, 1887, by monotypy.

Diagnosis (modified from Barnich \& Fiege 2003). Prostomium with sessile eyes, rarely missing; two lateral and one median antennae. Palps long, papillate; tentacular segment distinct dorsally, sometimes with chaetae. Segment 2 with elytra and long ventral cirrus. Parapodia biramous, without branchiae; notopodium reduced, notochaetae delicate, long capillaries; neuropodium projecting, neurochaetae of different kinds: long, slender, with many long spines in distal part; short, slender with few widespread spines; acicular with hirsute tip; lanceolate, twisted, with many whorls of spines. Pharynx with paired marginal papillae. Jaws 2 pairs, each with 3-8 teeth.

Remarks. Most diagnostic features are rather easy to discern; however, some notopodial features might be difficult to evaluate, because they are often reduced to a small notoacicular lobe, being better developed on anterior chaetigers, with notochaetae delicate and scarce, usually emerging below the lobe. On the middle and more posterior parapodia, notopodia are barely developed and notochaetae are often lost. Even in parapodial mounts, notopodia can be difficult to discern because notoacicula migrate ventrally, being placed slightly above neurochaetal bundle bases. However, notochaetae have a slightly different orientation, being directed obliquely from the bundle, whereas neurochaetae tend to have a more or less parallel orientation.

\section{Euarche rudipalpa (Amaral \& Nonato, 1984)} Figs $1-17$

Eupanthalis rudipalpa Amaral \& Nonato, 1984: 14, figs 1-11; Amaral et al., 2013: 18

Euarche tubifex: Pettibone, 1989: 14 [part].

Material examined. One specimen (UERJ 4024), Santos Basin (28 $09^{\prime} 57.6^{\prime \prime} \mathrm{S}, 48^{\circ} 33^{\prime} 50.4^{\prime \prime} \mathrm{W}$ to $\left.24^{\circ} 51^{\prime} 39.6^{\prime \prime} \mathrm{S}, 40^{\circ} 36^{\prime} 39.6^{\prime \prime} \mathrm{W}\right)$ Station 17, $2013 \mathrm{~m}$.

Body subcylindrical anteriorly, depressed medially and posteriorly, with wide, brownish dorsal band (Fig. 1), extending up to chaetiger 30, gradually narrowing, becoming finer and reaching posterior end (Fig. 5). Parapodia whitish, dorsally with two or three thin, transverse pigmented bands, ventrally whitish. Venter with deep longitudinal furrow reaching posterior end, with fine tiny brownish spots throughout; ventral cirrophores with pigmented glands (Fig. 6). Everted pharynx maculated, lateral papillae darker distally; marginal papillae pale, several with darker inner glands; jaws dark brown (Fig. 4). Palps pale brown, blunt, darker sub-distally, tips whitish, with longitudinal series of dark papillae running throughout their length, and several irregular, thin, brown rings (Figs 2, 3). Antennae and tentacular cirri maculated, darker or with larger spots ventrally. Prostomium and surrounding areas brownish, with shiny bluish hue dorsally, along a few anterior chaetigers (Fig. 3). Tentacular cirrophores dark brown, with digitiform projection near cirrostyle, cirrostyles paler, with some dark brown spots irregularly distributed. Prostomium oval, wider than long. Anterior eyes larger, half-moon shaped, posterior ones smaller, regularly distributed over prostomial surface. Lateral antennae on anterior prostomial margin, tapering, tips thin, pointed, brownish becoming paler distally; median antenna about as long as, or slightly longer than, lateral antennae, with ceratophore distinct, basal region darker 

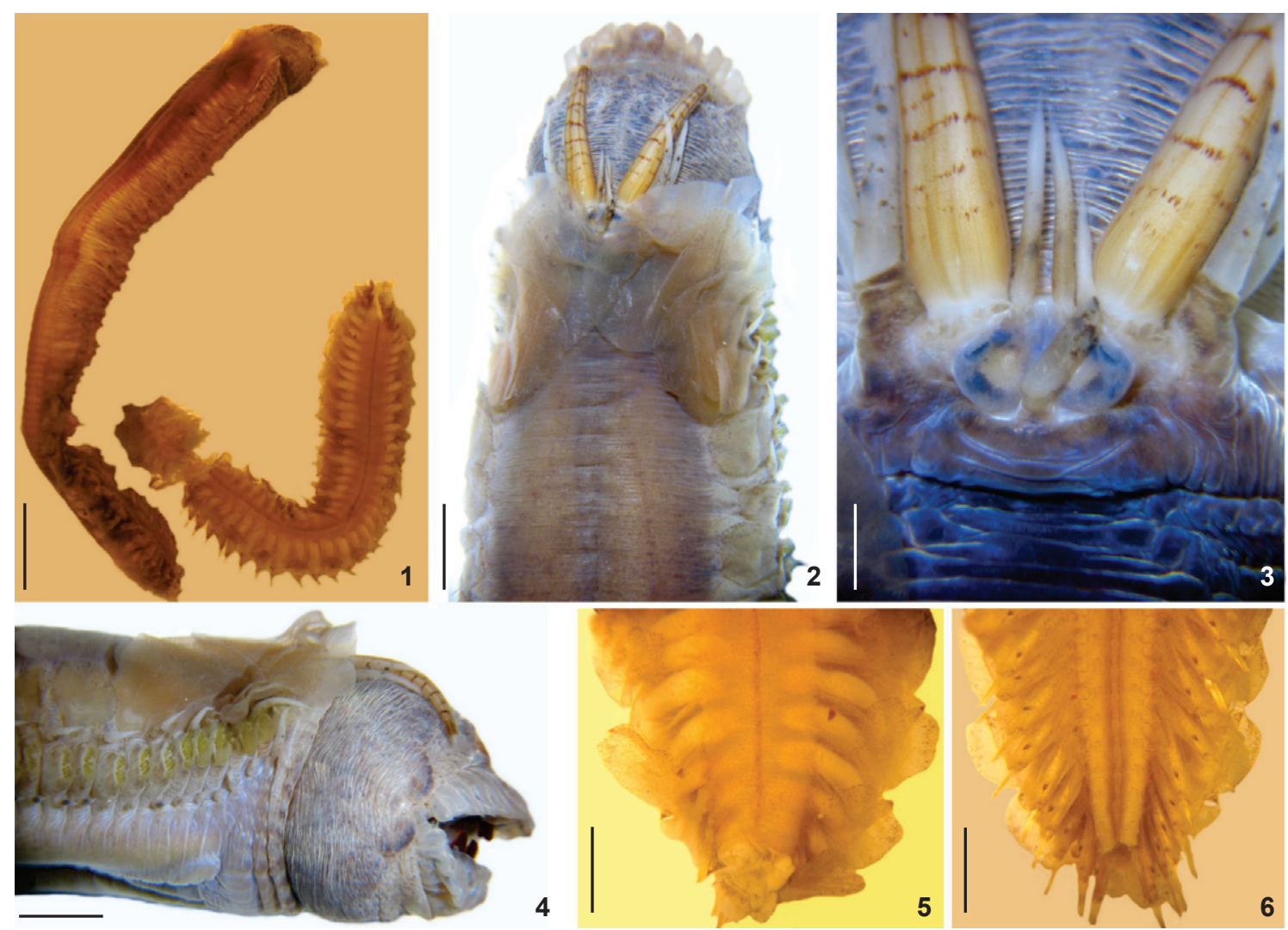

Figures 1-6. Euarche rudipalpa, (UERJ 4024): (1) anterior fragment in lateral view, posterior fragment in dorsal view; (2) anterior end, dorsal view; (3) same, without elytra from chaetiger 1 (chaetae of tentacular segment too transparent and delicate to be captured); (4) anterior end, lateral view; (5) posterior end, dorsal view; (6) same, ventral view. Scale bars: $1=11.3 \mathrm{~mm}, 2=3.3 \mathrm{~mm}, 3=0.9 \mathrm{~mm}, 4=$ $3.1 \mathrm{~mm}, 5=0.4 \mathrm{~m}, 6=0.3 \mathrm{~mm}$.

than distal half (whitish). Palps about three times longer than lateral antennae, about one-fourth longer than tentacular cirri. Tentacular segment (first chaetiger) reduced with abundant, delicate notochaetae and a notoaciculum. Second chaetiger with biramous parapodia and first pair of elytra. All parapodia biramous; anterior parapodia (Fig. 7) more prominent and pigmented than median (Fig. 8), or posterior ones (Fig. 9). Dorsal cirri globose basally,tapering distally to a fine tip, longer than neurochaetal fascicles in first 2-3 chaetigers, smaller in following chaetigers, barely reaching neurochaetal lobes in median or posterior chaetigers. Notochaetae reduced to few, delicate, smooth capillaries, decreasing in abundance and size in median and posterior chaetigers, situated very close to neurochaetal fascicles. Neuropodia with larger postchaetal lobe, margin more heavily pigmented; ventral cirri medially swollen, tapering to delicate tips, longer in first 3-4 chaetigers, smaller medially and posteriorly. Neurochaetae arranged in distinct series: larger neurochaetae in more or less radial series; smaller, lower chaetae in several series in a U-shaped pattern (Figs 4,10$)$. Superior supracicular neurochaetae arranged in a single series, of two kinds: long, slender with many long spines in distal part (Fig. 11) and shorter, with widespread spines; middle neurochaetae arranged in 5-7 series, acicular, penicillate, tip falcate, bidentate, with additional fibers giving an hirsute appearance (in middle and posterior parapodia 2-3 chaetae per series) (Fig. 12, insert); inferior neurochaetae in 3-4 series, lanceolate, twisted and medially swollen, with numerous whorls of spines (Fig. 13). Pharynx with 11 pairs of marginal papillae (Fig. 14), mid-ventral and mid-dorsal ones slightly longer; mid-dorsal papilla entire, mid-ventral papilla trilobed. On pharynx sides, two depressed, semicircular large basal papillae, and in the inner cavity, three accessory inner papillae dorsally and ventrally, some with a blunt projection. Jaws not fully exposed; teeth not visible. Insertion of elytra is on parapodia $2,4,5,7, \ldots$ until the end of the body. First pair of elytra large, ovoid, covering prostomium; following decreasing rapidly in size, small oval by chaetiger 10 , continuing to end of body. Elytra delicate, margin smooth (Fig. 16), surface with rounded microtubercles, more conspicuously towards posterior body (Fig. 17), and variable amounts of brownish spots, in 

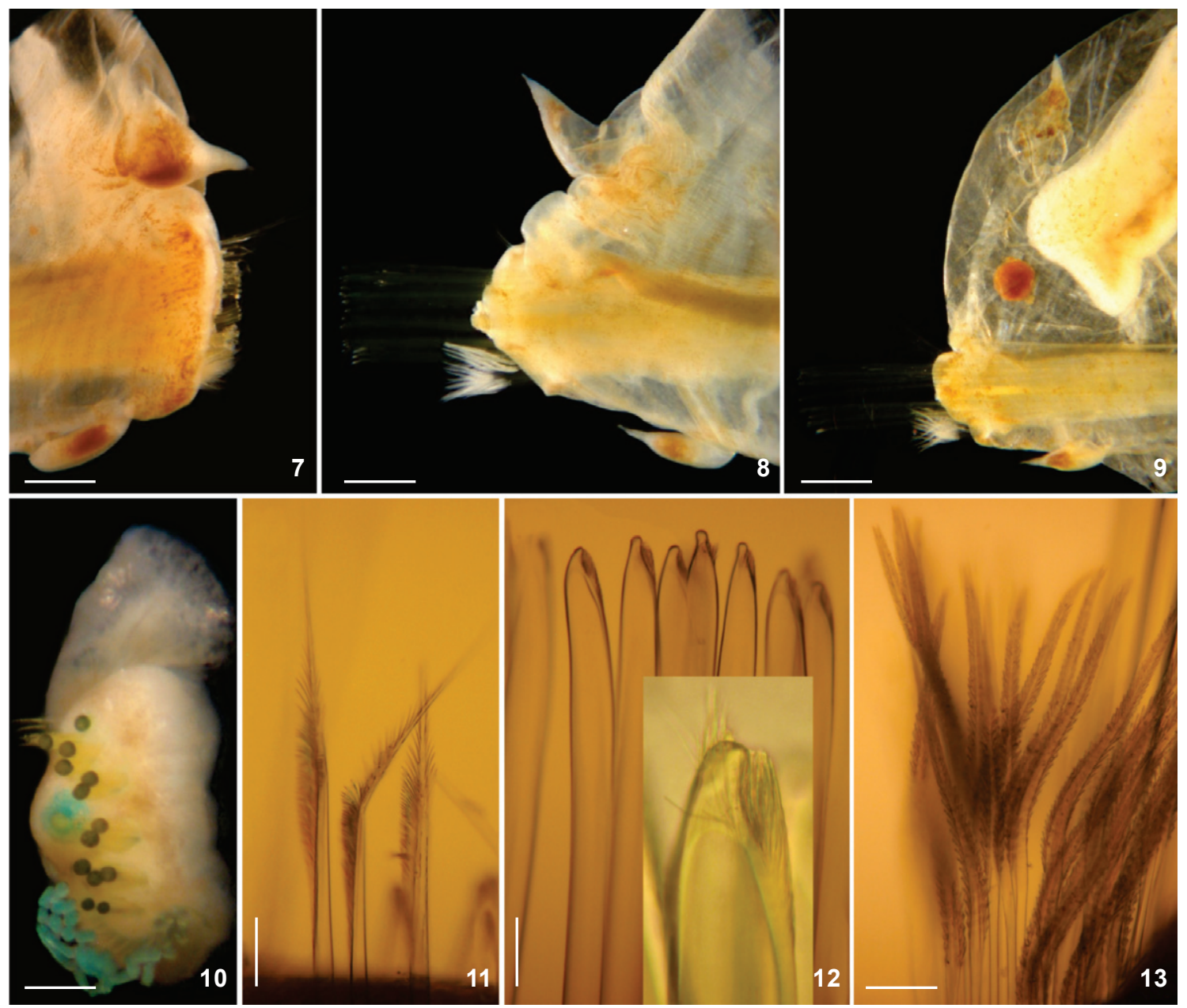

Figures 7-13. Euarche rudipalpa, (UERJ 4024): (7) chaetiger 17, right parapodium, posterior view; (8) chaetiger 42, right parapodium, anterior view; (9) chaetiger 98, right parapodium, anterior view with a dark orange oocyte; (10) chaetiger 60, left parapodium, frontal view, hirsute chaetae trimmed showing chaetal serial arrangement; (11) Chaetiger 17, upper neurochaetae with uniseriate chaetae; (12) chaetiger 42 , hirsute chaetae (insert: close-up of tip); (13) same, twisted spinulose chaetae. Scale bars: $7=0.6 \mathrm{~mm}, 8=0.8 \mathrm{~mm}$, $9=0.6 \mathrm{~mm}, 10=170 \mu \mathrm{m}, 11=50 \mu \mathrm{m}, 12=65 \mu \mathrm{m}, 13=70 \mu \mathrm{m}$.

some elytra especially abundant towards elytral margin. Pygidium damaged; anal cirri unknown.

Internal features: Enteron with lateral diverticula, penetrating parapodia as large caeca, visible by transparency as blunt opaque lobes (Fig. 9), with thick walls (Fig. 15), starting from about chaetiger 15. Dark-orange to brownish oocytes sparse in some posterior chaetigers, pale in ovary, dark orange or brownish once detached, reaching about $250 \mu \mathrm{m}$ in diameter (Fig. 9).

Distribution. Brazil, off state of Rio Grande do Sul and Santos Basin, at $195 \mathrm{~m}$ depth in medium sand (in original description), now extended to deep water (2013 m).

Remarks. This specimen mostly fits the original description of Eupanthalis rudipalpa Amaral \& Nonato, 1984 but di- rect comparison with type material was not possible because the type specimens seem to be lost (Mônica Petti, pers. com.). Due to the presence of three antennae, and palps with papillae throughout their length, the species must be transferred to Euarche Ehlers, 1887, as already indicated by Pеттівone (1989: 14). Eupanthalis rudipalpa must be reinstated because it clearly differs from other species in the genus, as shown in the key below. Euarche rudipalpa resembles E. tubifex in the size of the anterior eyes, which are about twice as large as the posterior ones. This similarity might explain why the two species were regarded as synonyms. However, E. rudipalpa and E. tubifex differ in the relative size of antennae and palps, and in the relative extent of papillae series along palps. In E. rudipalpa, papillae extend throughout the palps, and palps are about three times 

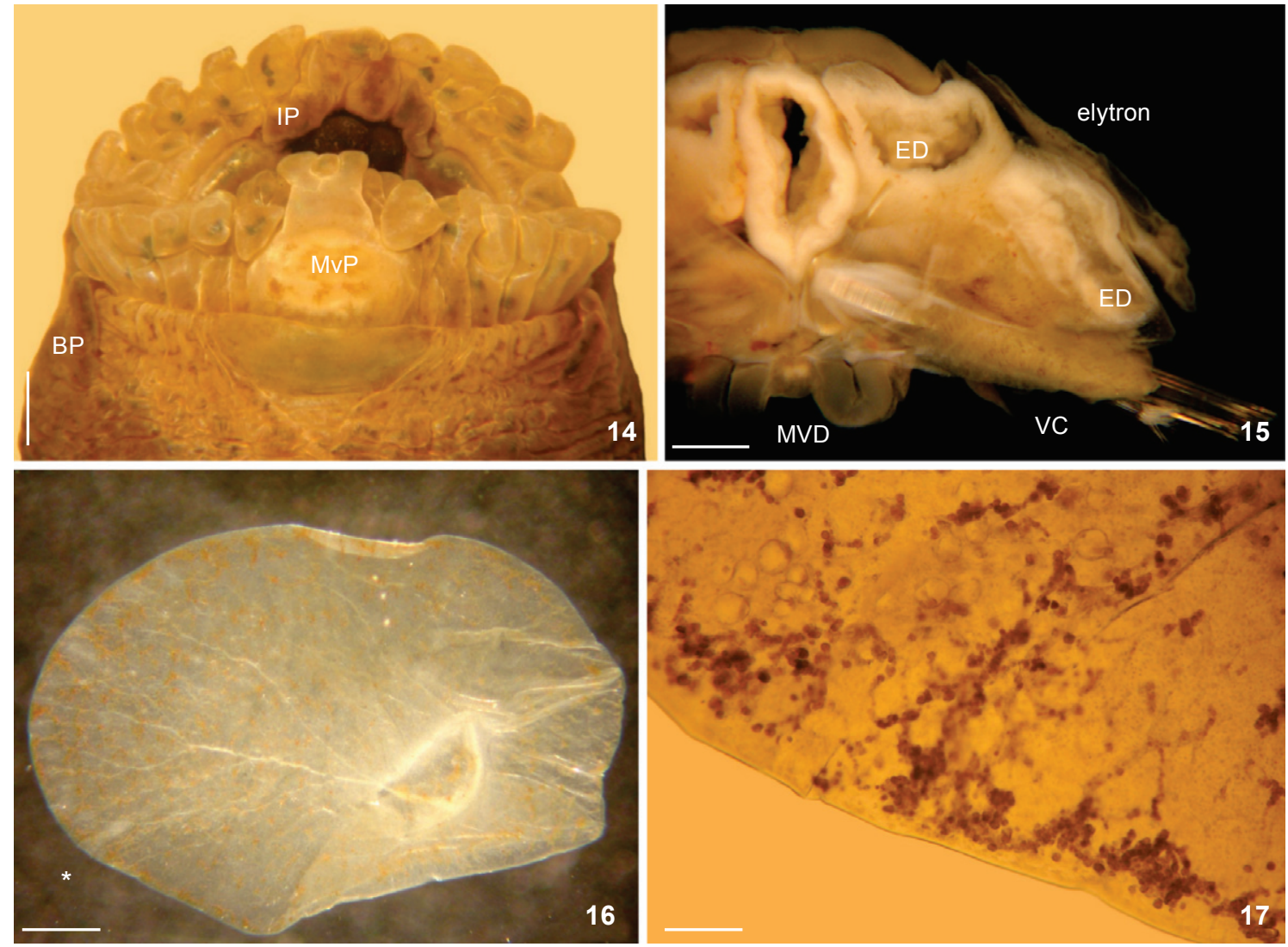

Figures 14-17. Euarche rudipalpa, (UERJ 4024): (14) pharynx, oblique ventral view; (15) chaetiger 60, posterior view, transverse cut; (16) right elytron from chaetiger 8, frontal view (*enlarged area in Fig. 17); (17) same, close-up of dorsal, posterior, marginal area showing brownish spots and microtubercles. (BP) basal papilla, (ED) enteric diverticulum, (IP) internal papilla, (MVD) mid-ventral depression, (MvP) mid-ventral papilla, (VC) ventral cirrus. Scale bars: $14=1.7 \mathrm{~mm}, 15=1 \mathrm{~mm}, 16=0.5 \mathrm{~mm}, 17=65 \mu \mathrm{m}$.

longer than lateral antennae, whereas in E. tubifex papillae extend on the distal two-thirds of palps, and palps are about twice as long as lateral antennae.

Recent compilations (Hutchings 2000) have mentioned the presence of enteric diverticula in the parapodia of Acoetidae; however, only one plate containing some illustrations is available for this feature. It was provided by Delle Chiaje (1841b: pl. 99) for Polyodontes maxillosa (Ranzani, 1817), without any explanation for the figures. The author only provided a Latin diagnosis for the species. These illustrations were not reproduced from earlier works, including the original description (RANZANi 1817), and show complex enteric diverticula penetrating the parapodia, separated by constricted tunnels. Each diverticulum has lateral and distal sacs per segment; two other globose structures were regarded as testis, perhaps, because they were indicated with a letter " $\mathrm{t}$ ". The second illustration was provided by Sтоксн (1968: 268, fig. 4) for a cross section of an anterior segment of Panthalis oerstedi Kinberg, 1856, but he provided little information about lateral caeca. In E. rudipalpa, lateral connections were not observed probably because the gut was too contracted, but their extensions inside parapodia are confirmed. McINTOSH (1900: 402) indicated that in P. oerstedi enteric caeca were "large and elliptical, with a narrow neck", and this was illustrated by STORCH (1968).

\section{Key to species of Euarche Ehlers, $1887^{1}$ (modified from PetTibone 1989)}

1. Prostomium oval, without anterior furrow; eyes present. 2

1 '. Prostomium bilobed, with anterior furrow; eyes absent; palps 4.0-4.5 longer than lateral antennae (Gulf of Mexico) ..... E. mexicana Pettibone, 1989

2. Anterior and posterior eyes about same size ..................... 3

2 '. Anterior eyes twice as large as posterior ones .................. 5

3. Palps 3 times longer than lateral antennae ....................... 4

3 '. Palps twice as long as lateral antennae; eyes on widest part of prostomium (Mediterranean Sea)....

E. tubifex sensu Barnich \& Fiege (2003) 
3". Palps 4 times longer than lateral antennae; eyes regularly distributed on prostomium (Philippine Islands) ......

E. maculosa (Treadwell, 1931)

4. Eyes regularly distributed on prostomium (Congo) ............. Euarche sp.

$4^{\prime}$. Eyes displaced towards posterior part of prostomium (Pacific Panama) E. perlae (Fauchald, 1977) ${ }^{2}$

5. Palps 2.0-2.5 times longer than lateral antennae (up to 5 times in original illustration), longitudinal rows of papillae extended over $2 / 3$ of palp length; antennae of about the same length (Gulf of Mexico) ....... E. tubifex Ehlers, $1887^{3}$

5'. Palps about three times longer than lateral antennae, longitudinal rows of papillae extended throughout their length; median and lateral antennae about same length (Brazil [E. tubifex sensu PALmero et al. (2008) is very similar]) E. rudipalpa (Amaral \& Nonato, 1984)

\section{Key notes:}

${ }^{1}$ Euarche cristata Núñez in PALmERo et al. (2008) does not belong to this genus because it lacks the median antenna. It should be either a. transferred to Eupanthalis, being similar to $E$. kinbergi but differing by having papillae all over the palps (instead of having smooth palps); or b. proposed as the type species of a new genus based on the posterior prostomial crest, which is unique among acoetid genera.

${ }^{2}$ Euarche cristata was regarded as another junior synonym of $E$. tubifex but its status as a separate species needs to be maintained; further, E. tubifex sensu IмаJімa (1997) from Japan differs by having chaetiger 1 with granulose dorsal surface, fusiform tentacular cirri, and a single series of inferior most neurochaetae in median chaetigers.

${ }^{3}$ Barnich \& Fiege (2003) showed that Pettibone's (1989) redescription of Eupanthalis rudipalpa was based on a mixture of specimens and clarified the differences between Eupanthalis and Euarche. The series upon which Eupanthalis sp. (Wolf 1984) was based included specimens that have poorly defined eyes and have palps of different sizes. We believe that it either includes one specimen in regeneration or two different species. It cannot be keyed out. Further, Peтtibone (1989) included in Euarche two specimens from the Arabian Sea, identified as Eupanthalis kinbergi by Hartman (1938). Formerly deposited in the Allan Hancock Foundation, they are now in the Los Angeles County Museum, but they might belong to a different species. WeHE \& FIEGE (2002) listed other records for the Indian Ocean. Because these records were not illustrated, they cannot be included in the key.

\section{ACKNOWLEDGEMENTS}

Biodiversity Heritage Library, CiNii, GoogleBooks, Internet Archive, Ruth Barnich, Dieter Fiege both from SMF, Wagner Magalhães (University of Hawaii), and Luis F. Carrera-Parra (ECOSUR) provided important references for this research. Ruth
Barnich and an anonymous reviewer critically read earlier drafts and made significant improvements to this final document. We also thank Mônica Petti (IO/USP) for helping us with the Prof. Edmundo F. Nonato biological collection. SISV had a visiting professor scholarship from the Universidade do Estado do Rio de Janeiro (UERJ).

\section{LITERATURE CITED}

Amaral, A.C.Z. \& E.F. Nonato. 1984. Anelídeos Poliquetos da Costa Brasileira: Polyodontidae, Pholoidae, Sigalionidae e Eulepethidae. Brasília, CNPq, Programa Nacional de Zoologia, Série Manuais de Identificação da Fauna Brasileira, 54p.

Amaral, A.C.Z.; S.A.H. NAluin; T.M. Steiner; T.O. Forroni \& D.G. FILHO. 2013. Catálogo das espécies de Annelida Polychaeta do Brasil. Campinas, Unicamp, 183p. Available online at: http:// www.ib.unicamp.br/museu_zoologia/files/lab_museu_zoologia/ Cat\%C3\%A1logo_Polychaeta_Brasil_Amaral_et_al_2013_1a.pdf

Augener, H. 1918. Polychaeta. Hamburg, Beiträge zur Kenntnis des Meeresfauna Westafrikas, Herausgegeben von W. Michaelsen (Hamburg), L. Friederichsen \& Co., vol. 2, p. 67-625.

BAIRD, W. 1868. Contributions to a monograph of the Aphroditacea. Journal of the Linnean Society of London 9: 31-38.

Barnich, R. \& D. Fiege. 2003. The Aphroditoidea (Annelida: Polychaeta) of the Mediterranean Sea. Abhandlungen der senckenbergischen naturforschenden Gesellschaft 559: 1-167.

Ben-Eliahu, M.N. \& D. Fiege. 1994. Polychaetes of the family Acoetidae (= Polyodontidae) from the Levant and the Central Mediterranean with a description of a new species of Eupanthalis. Mémoires du Muséum National d'Histoire Naturelle 162: 145-161.

Buchanan, F. 1894. A polynoid with branchiae (Eupolyodontes cornishii). Quarterly Journal of Microscopial Science, New Series, 35: 433-450.

Darboux, J.G. 1899. Recherches sur les aphroditiens. Travaux de l'Institut de Zoologie de l'Université de Montpellier et de la Station maritime de Cette 6: 1-276.

Delle Chiaje, S. 1841b. Descrizione e Notomia degli Animali Invertebrati della Sicilia Citeriore observati Vivi negli Anni 1822-1830, VII. Napoli, Batelli Comp.

Ehlers, E. 1887. Report on the Annelids. Reports on the Result of Dredging, under the Direction of Pourtales \& Agassiz in the Gulf of Mexico. Memoires of the Museum of Comparative Zoology, Harvard 15: 1-335.

Fauchald, K. 1977. The Polychaete Worms: Definitions and Keys to the Orders, Families and Genera. Natural History Museum of Los Angeles County, Science Series, 28: 1-188.

Fauvel, P. 1897. Observations sur l'Eupolyodontes cornishii Buchanan (Annélide polychète errante). Bulletin de la Société Linnéenne de Normandie, 5e série 1: 88-112.

Fauvel, P. 1914a. Annélides polychètes non pélagiques des campagnes de l'Hirondelle et de la Princesse-Alice (18851910). Résultats des Campagnes Scientifiques accomplies 
sur son Yacht par Albert 1er Prince Souverain de Monaco 46: 1-432.

Fauvel, P. 1914b. Sur la classification des Acoetines (Annélides Polychètes), p. 468-473. In: IXe Congrès Internationa de Zoologie. Monaco, Section III, Zoologie systématique, Moeurs des Animaux.

Grube, A.E. 1876. Bemerkungen über die Familie der Aphrodditeen (Gruppe Polynoina, Acoëtea, Polylepidea). Jahres-Bericht der Schlesiche Gesellschaft für vaterlandische Cultur, Breslau 53: 46-72.

HARTMAN, O. 1938. Annotated list of the types of poychaetous annelids in the Museum of Comparative Zoology. Bulletin of the Museum of Comparative Zoology, Harvard 85: 1-31.

Hutchings, P.A. 2000. Family Acoetidae, p. 112-115. In: P.L. Beesley; G.J.B. Ross \& C.J. Glasby (Eds). Polychaetes \& Allies: The Southern Synthesis. Fauna of Australia, 4A. Polychaeta, Myzostomida, Pogonophora, Echiura, Sipuncula. Melbourne, CSIRO Publishing.

ImAJIMA, M. 1997. Polychaetous annelids from Sagami Bay and Sagami Sea collected by the Emperor Showa of Japan and deposited at the Showa Memorial Institute, National Science Museum, Tokyo. National Science Museum Monographs, Tokyo 13: 1-131.

McIntosh, W.C. 1876. On the Annelida of the 'Porcupine' Expeditions of 1869 and 1870, 1. Euphrosyinidae, Amphinomidae, Aphroditidae, Polynoidae, Acoëtidae, and Sigalionidae. Transactions of the Zoological Society of London 9: 395-416.

McIntosh, W.C. 1900. A Monograph of the British Annelids, Part 2. Polychaeta: Amphinomidae to Sigalionidae. London, Ray Society, vol. 1, p. 215-442.

Monro, C.C.A. 1928. Polychaeta of the families Polynoidae and Acoetidae from the vicinity of the Panama Canal, collected

Submitted: 16.XII.2013; Accepted: 04.V.2014.

Editorial responsibility: Paulo da Cunha Lana by Dr. C. Crossland and Dr. Th. Mortensen. Journal of the Linnean Society 36: 553-576.

Palmero, A.M.; A. Martínez; M.C. Brito \& J. Núñez. 2008. Acoetidae (Annelida, Polychaeta) from the Iberian Peninsula, Madeira and Canary Islands, with description of a new species. Arquipélago, Life and Marine Sciences 25: 49-62.

Pettibone, M.H. 1989. Revision of the aphroditoid polychaetes of the family Acoetidae Kinberg (= Polyodontidae Augener) and reestablishment of Acoetes Audouin and Milne-Edwards, 1832, and Euarche Ehlers, 1887. Smithsonian Contributions to Zoology 464: 1-138.

Pruvot, G. \& E.-G. Racovitza. 1895. Matériaux pour la faune des annélides de Banyuls. Archives de Zoologie Expérimentale et Générale, troisième Série 3: 339-492.

RANZANI, C. 1817. Descrizione di un animale che appartiene ad un nuovo genere della Classe degli Anellidi. Opuscoli Scientifici 1: 105-109.

Sтовсн, V. 1968. Zur vergleichenden Anatomie der segmentalen Muskelsystem und zur Verwandtschaft der PolychaetenFamilien. Zeitschrift für Morphologie der Tiere 63: 251342.

TreadWell, A.L. 1931. Four new species of polychaetous annelids collected by the United States Fisheries Steamer Albatross during the Philippine Expedition of 1907-1910. Bulletin of the United States National Museum 100 (5): 313-321.

Wehe, T. \& D. Fiege. 2002. Annotated checklist of the polychaete species of the seas surrounding the Arabian Peninsula: Red Sea, Gulf of Aden, Arabian Sea, Gulf of Oman, Arabian Gulf. Fauna of Arabia 19: 7-238.

Wolf, P.S. 1984. Family Polyodontidae Buchanan, 1894, p. 22.122.10. In: J.M. Uebelacker, \& P.G. JoHnson (Eds). Taxonomic Guide to the Polychaetes of the Northern Gulf of Mexico. Mobile, Barry A. Vittor. 